\title{
KONSEP MENUMBUHKAN KETERAMPILAN BERBAHASA INDONESIA BAGI ANAK MELALUI METODE BERMAIN
}

\begin{abstract}
Aniati
Abstract

The world of play is the world of children. Fostering Indonesian language skills for children through play methods is a way of developing language skills with the goal of conveying ideas, ideas, concepts, and feelings through reading, listening, writing and speaking. By using play methods to foster language skills for children, such as guessing pictures, word games, chain whispers, crossword puzzles, role playing, traveling, drama, intelligent meticulous, ready to carry out orders, and make cooperation. These methods are tailored to the child's ability to receive the required material. The steps taken in fostering children's language skills through play methods include: Determining the purpose and theme of play activities, determining the kinds of play activities, determining the place and play space, determining materials and play equipment, and determining the sequence of play steps. Thus, children's language skills will grow along with the growth of activities expressed in everyday life.
\end{abstract}

Keyword: Developing, Indonesian languageskill, playing method

\section{PENDAHULUAN}

Keterampilan berbahasa terdiri dari keterampilan berbahasa tulis dan keterampilan berbakkhasa lisan. Implikasinya difokuskan pada kemampuan anak memahami dan menggunakan bahasa sebagai alat komunikasi dalam kehidupan sehari-hari. Bahasa merupakan salah satu alat untuk mengadakan interaksi terhadap manusia yang lain. Jadi bahasa tersebut tidak dapat dipisahkan dengan manusia. Dengan adanya bahasa kita, kita dapat berhubungan dengan 
masyarakat lain yang akhirnya melahirkan komunikasi dalam masyarakat. Untuk terampil memahami dan menggunakan bahasa diperlukan landasan kebahasaan yang kuat.

Hakikat bahasa secara sederhana merupakan alat untuk berinteraksi dan berkomunikasi, yang bertujuan menyampaikan sesuatu, baik berupa pemikiran, gagasan, konsep, atau perasaan melalui alat ucap. Intinya, bahwa bahasa merupakan alat komunikasi bagi manusia untuk saling berinteraksi. Bahasa merupakan salah satu alat untuk mengadakan interaksi terhadap manusia yang lain. Jadi bahasa tersebut tidak dapat dipisahkan dengan manusia. Dengan adanya bahasa kita, kita dapat berhubungan dengan masyarakat lain yang akhirnya melahirkan komunikasi dalam masyarakat.

Dunia bermain adalah dunia yang penuh warna dan menyenangkan. Para pelaku permainan akan merasa terhibur dan senang dengan melakukannya. Dari kata "bermain" saja sudah menunjukan bahwa kegiatan ini berdampak memberikan penyegaran pikiran dari berbagai aktifivitas yang menjenuhkan. Bagi anak-anak, bermain memiliki peranan yang sangat penting. Beberapa pakar psikologi berpendapat bahwa kegiatan bermain dapat menjadi sarana untuk perkembangan anak. Dengan melakukan permainan, anak-anak akan terlatih secara fisik. Dengan demikian kemampuan kognitif dan sosialnyapun akan berkembang. Singkatnya, permainan dimasa kecil akan mempengaruhi pertumbuhan fisik dan perkembangan jiwa anak kelak. Anak lebih suka suasana bebas tanpa ada tekanan, berinteraksi dengan teman, dan bermain. Bermain dan permainan merupakan hal yag sangat dekat dengan dunia anak.

Suhendi menjelaskan bahwa setiap diri manusia, baik anakanak maupun orang dewasa terdapat hasrat untuk bermain. Seperti halnya kebutuhan bersosialisasi dan berkelompok, bermain merupakan hasrat yang mendasar pada diri manusia. Anak-anak ingin bermain karena saat itulah mereka mendapatkan berbagai 
pengalaman lewat bermain melalui eksplorasi alam di sekitarnya. Dari kegiatan tersebut, mereka dapat mengenal alam dan teman sepermainan dalam suasana yang menyenangkan. Sementara orang dewasa membutuhkan permainan sebagai sarana relaksasi dan menghibur diri. ${ }^{1}$

Salah satu yang dapat dilakukan sebagai kreator, pemimpin dan pembimbing permainan untuk menumbuhkan keterampilan berbahasa pada anak melalui metode permainan, harus jeli dan kreatif mengoptimalkan permainan baik di sekolah maupun di rumah agar kecerdasan anak dapat dioptimalkan. Maka, terus digali kemampuannya dalam memilih permainan yang kreatif, inovatif, tepat sasaran, dan harus tetap menyenangkan. Sebab anak merupakan masa yang sangat rentan, karena pada masa ini otak anak mengalami percepatan perkembangan hingga $80 \%$ dari keseluruhan otak orang dewasa. Hal ini menunjukkan bahwa seluruh potensi dan kecerdasan serta dasar-dasar perilaku seseorang telah mulai terbentuk pada usia ini. Pentingnya masa ini sehingga usia dini anak sering disebut sebagai masa golden age yaitu dimana otak anak berkembang sangat cepat. Pemberian stimuli yang tepat akan sangat mempengaruhi perkembangan selanjutnya, yang meliputi stimuli untuk perkembangan motorik, kognitif, bahasa, sosial emosional, dan agama moral. Masa usia dini merupakan periode emas (golden age) bagi perkembangan anak untuk memperoleh proses pendidikan". ${ }^{2}$ Periode ini adalah tahun-tahun berharga bagi seorang anak untuk mengenali berbagai macam fakta di lingkungannya sebagai stimulans terhadap perkembangan kepribadian, psikomotorik, kognitif maupun sosialnya

${ }^{1}$ Suhendi, A., dkk Mainan dan Permainan. (Jakarta: PT. Gramedia. 2001), h. 8. 2009), hlm.7

${ }^{2}$ Danar Santi, Pendidikan Anak Usia Dini, (Cet.I., Jakarta: PT. Indeks, 
Metode adalah cara rencana menyeluruh mengenai penyajian bahasa secara sistematis berdasarkan pendekatan yang dilakukan dalam menentukan metode yang tepat harus berdasarkan pada tujuan psikologi perkembangan anak dan filsafat kemampuan anak. Oleh karena itu implementasi setiap metode tertentu dalam pembelajaran bahasa setidaknya mencakup 4 aktifitas utama yaitu seleksi, gradasi, presentasi dan repetisi. Kegiatan seleksi berkaitan dengan kegiatan memilih materi kebahasaan yang akan diajarkan. Setelah itu langkah selanjutnya adalah melakukan gradasi atau pentahapan dan penelitian materi yang akan diajarkan. Materi paling mudah disampaikan terlebih dahulu dari pada materi yang lain begitu seterusnya. Langkah berikutnya menyajikan materi yang telah dipilih dan diurutkan tersebut dalam kelas. Sedangkan repetisi atau pengulangan pada dasarnya diperlukan untuk menguatkan sesuatu yang telah di sampaikan dalam presentasi ${ }^{3}$.

Banyak sekali bentuk bermain yang dapat dikaitkan dengan keterampilan berbahasa anak, seperti: permainan berhitung menggunakan jari dan kartu, permainan menebak tanggal lahir orang lain, permainan computer online, permainan papan, mencari arah, dan pencarian sesuatu dengan buku. Akan tetapi metode-metode bermain yang digunakan untuk menumbuhkan keterampilan berbahasa bagi anak, seperti: menebak gambar, permainan kata, bisik berantai, teka-teki silang, bermain peran, berwisata, drama, cerdas cermat, siap melaksanakan perintah, dan mengarang gotong royong. Metode-metode tersebut disesuaikan dengan kemampuan anak menerima materi yang diperlukan. Oleh karena itu, dunia bermain adalah dunia anak yang paling dominan. Keterampilan berbahasa anak akan tumbuh bersamaan dengan tumbuhnya kegiatan yang diekspresikan dalam kehidupan sehari-hari.

\footnotetext{
${ }^{3}$ Syamsuddin Asyrofi, dkk, Metodologi pembelanjaran Bahasa Arab, (Yogyakarta: Pokja Akademik UIN Sunan Kalijaga, 2006), hlm. 82
} 
Berdasarkan latar belakang di atas, maka yang menjadi pokok rmasalah bagaimana konsep menumbuhkan keterampilan berbahasa pada anak melalui metode bermain?

\section{PEMBAHASAN}

\section{a. Hakikat Bahasa}

Dalam Kamus Besar Bahasa Indonesia, pengertian bahasa adalah sistem lambang bunyi yang arbitrer, yang digunakan oleh semua orang atau anggota masyarakat untuk bekerjasama, berinteraksi, dan mengidentifikasikan diri, percakapan yang baik, tingkahlaku yang baik, dan sopan santun. ${ }^{4}$

Kridalaksana mengatakan bahwa bahasa merupakan alat komunikasi yang dipakai oleh masyarakat untuk mengekspresikan gagasan yang telah menjadi konsesus bersama. Ekspresi bahasa tersebut menggambarkan kecendrungan masyarakat penuturnya. Oleh karenanya, untuk mempelajari dan menjelaskan bahasa niscaya harus melibatkan aspek-aspek sosial yang mencitrakan masyarakat. ${ }^{5}$ Beberapa faktor yang berhubungan dengan perbedaan bahasa antara laki-laki dan perempuan, diantaranya adalah faktor suara dan intonasi.

Berbeda dengan apa yang dikatakan oleh Chomsky bahwa bahasa adalah asosial karena mengabaikan heterogenitas yang ada dalam masyarakat, baik status sosial, pendidikan, umur, jenis kelamin latar belakang budayanya, dan lain-lain. Chomsky memilah antara bahasa di satu sisi dan budaya di sisi lain. Dalam mempelajari bahasa yang berhubungan dengan sosial budaya akan menghasilkan empat kemungkinan. Pertama, struktur sosial dapat mempengaruhi

\footnotetext{
${ }^{4}$ Departemen Pendidikan Nasional, Kamus Besar Bahasa Indonesia (Jakarta: Departemen Pendidikan Nasional, 2008), 88.

${ }^{5}$ Harimurti Kridalaksana, Fungsi Bahasa dan Sikap Bahasa (Flores: Nusa Indah, 1985), 4.
} 
dan menentukan struktur atau perilaku bahasa. Kedua, struktur dan perilaku bahasa dapat mempengaruhi dan menentukan struktur sosial. Ketiga, hubungan keduanya adalah timbal balik. Keempat, struktur sosial dan struktur bahasa sama sekali tidak berhubungan. ${ }^{6}$ Inilah yang dianut oleh Chomsky. Bila kita mengambil kemungkinan pertama, maka bahasa adalah hasil konsensus masyarakat

.Menurut Gorys Keraf, Bahasa adalah alat komunikasi antara anggota masyarakat berupa simbol bunyi yang dihasilkan oleh alat ucap manusia. ${ }^{7}$ Mungkin ada yang keberatan dengan mengatakan bahwa bahasa bukan satu-satunya alat untuk mengadakan komunikasi. Mereka menunjukkan bahwa dua orang atau pihak yang mengadakan komunikasi dengan mempergunakan cara-cara tertentu yang telah disepakati bersama. Lukisan-lukisan, asap api, bunyi gendang atau tong-tong dan sebagainya. Tetapi mereka itu harus mengakui pula bahwa bila dibandingkan dengan bahasa, semua alat komunikasi tadi mengandung banyak segi yang lemah.

Bahasa memberikan kemungkinan yang jauh lebih luas dan kompleks daripada yang dapat diperoleh dengan mempergunakan media tadi. Bahasa haruslah merupakan bunyi yang dihasilkan oleh alat ucap manusia. Bukannya sembarang dalam berkomunikasi sehari-hari, salah satu alat yang paling sering digunakan adalah bahasa, baik bahasa lisan maupun bahasa tulis. Begitu dekatnya kita kepada bahasa, terutama bahasa Indonesia, sehingga tidak dirasa perlu untuk mendalami dan mempelajari bahasa Indonesia secara lebih jauh. Akibatnya, sebagai pemakai bahasa, orang Indonesia tidak terampil menggunakan bahasa. Suatu kelemahan yang tidak disadari.

${ }^{6}$ Ronald Wardhaugh, An Intriduction to Lingusitics (New York: Basil, Blackwell, 1986), hal.

${ }^{7}$ Keraf, Gorys. Komposisi: Sebuah Pengantar Kemahiran Bahasa (Ende: Nusa Indah, 1993), 
Komunikasi lisan atau nonstandar yang sangat praktis menyebabkan kita tidak teliti berbahasa. Akibatnya, kita mengalami kesulitan pada saat akan menggunakan bahasa tulis atau bahasa yang lebih standar dan teratur. Pada saat dituntut untuk berbahasa' bagi kepentingan yang lebih terarah dengan maksud tertentu, kita cenderung kaku. Kita akan berbahasa secara terbata-bata atau mencampurkan bahasa standar dengan bahasa nonstandar atau bahkan, mencampurkan bahasa atau istilah asing ke dalam uraian kita. Padahal, bahasa bersifat sangat luwes, sangat manipulatif. Kita selalu dapat memanipulasi bahasa untuk kepentingan dan tujuan tertentu. Lihat saja, bagaimana pandainya orang-orang berpolitik melalui bahasa. Kita selalu dapat memanipulasi bahasa untuk kepentingan dan tujuan tertentu. Agar dapat memanipulasi bahasa, kita harus mengetahui fungsi-fungsi bahasa.

Pada dasarnya, bahasa memiliki fungsi-fungsi tertentu yang digunakan berdasarkan kebutuhan seseorang, yakni sebagai alat untuk mengekspresikan diri, sebagai alat untuk berkomunikasi, sebagai alat untuk mengadakan integrasi dan beradaptasi sosial dalam lingkungan atau situasi tertentu, dan sebagai alat untuk melakukan kontrol sosial. Derasnya arus globalisasi di dalam kehidupan kita akan berdampak pula pada perkembangan dan pertumbuhan bahasa sebagai sarana pendukung pertumbuhan dan perkembangan budaya, ilmu pengetahuan dan teknologi.

Hasil pendayagunaan daya nalar itu sangat bergantung pada ragam bahasa yang digunakan. Pembiasaan penggunaan bahasa Indonesia yang baik dan benar akan menghasilkan buah pemikiran yang baik dan benar pula. Kenyataan bahwa bahasa Indonesia sebagai wujud identitas bahasa Indonesia menjadi sarana komunikasi di dalam masyarakat modern. Bahasa Indonesia bersikap luwes sehingga mampu menjalankan fungsinya sebagai sarana komunikasi masyarakat modern. 
a. Bahasa sebagai Alat Ekspresi Diri

Pada awalnya, seorang anak menggunakan bahasa untuk mengekspresikan kehendaknya atau perasaannya pada sasaran yang tetap, yakni ayah-ibunya. Dalam perkembangannya, seorang anak tidak lagi menggunakan bahasa hanya untuk mengekspresikan kehendaknya, melainkan juga untuk berkomunikasi dengan lingkungan di sekitarnya. Setelah kita dewasa, kita menggunakan bahasa, baik untuk mengekspresikan diri maupun untuk berkomunikasi. Seorang penulis mengekspresikan dirinya melalui tulisannya. Sebenarnya, sebuah karya ilmiah pun adalah sarana pengungkapan diri seorang ilmuwan untuk menunjukkan kemampuannya dalam sebuah bidang ilmu tertentu. Jadi, kita dapat menulis untuk mengekspresikan diri kita atau untuk mencapai tujuan tertentu.

Sebagai contoh lainnya, tulisan kita dalam sebuah buku, merupakan hasil ekspresi diri kita. Pada saat kita menulis, kita tidak memikirkan siapa pembaca kita. Kita hanya menuangkan isi hati dan perasaan kita tanpa memikirkan apakah tulisan itu dipahami orang lain atau tidak. Akan tetapi, pada saat kita menulis surat kepada orang lain, kita mulai berpikir kepada siapakah surat itu akan ditujukan.

Kita memilih cara berbahasa yang berbeda kepada orang yang kita hormati dibandingkan dengan cara berbahasa kita kepada teman kita.

Pada saat menggunakan bahasa sebagai alat untuk mengekspresikan diri, si pemakai bahasa tidak perlu mempertimbangkan atau memperhatikan siapa yang menjadi pendengarnya, pembacanya, atau khalayak sasarannya. Ia menggunakan bahasa hanya untuk kepentingannya pribadi. Fungsi ini berbeda dari fungsi berikutnya, yakni bahasa sebagai alat untuk berkomunikasi.

Sebagai alat untuk menyatakan ekspresi diri, bahasa menyatakan secara terbuka segala sesuatu yang tersirat di dalam dada kita, 
sekurang-kurangnya untuk memaklumkan keberadaan kita. Unsurunsur yang mendorong ekspresi diri antara lain : - agar menarik perhatian orang lain terhadap kita,

- keinginan untuk membebaskan diri kita dari semua tekanan emosi

Pada taraf permulaan, bahasa pada anak-anak sebagian berkembang sebagai alat untuk menyatakan dirinya sendiri. ${ }^{8}$

b. Bahasa sebagai Alat Komunikasi

Komunikasi merupakan akibat yang lebih jauh dari ekspresi diri. Komunikasi tidak akan sempurna bila ekspresi diri kita tidak diterima atau dipahami oleh orang lain. Dengan komunikasi pula kita mempelajari dan mewarisi semua yang pernah dicapai oleh nenek moyang kita, serta apa yang dicapai oleh orang-orang yang sezaman dengan kita.

Sebagai alat komunikasi, bahasa merupakan saluran perumusan maksud kita, melahirkan perasaan kita dan memungkinkan kita menciptakan kerja sama dengan sesama warga. Ia mengatur berbagai macam aktivitas kemasyarakatan, merencanakan dan mengarahkan masa depan kita.

Pada saat kita menggunakan bahasa sebagai alat komunikasi, kita sudah memiliki tujuan tertentu. Kita ingin dipahami oleh orang lain. Kita ingin menyampaikan gagasan yang dapat diterima oleh orang lain. Kita ingin membuat orang lain yakin terhadap pandangan kita. Kita ingin mempengaruhi orang lain. Lebih jauh lagi, kita ingin orang lain membeli hasil pemikiran kita. Jadi, dalam hal ini pembaca atau pendengar atau khalayak sasaran menjadi perhatian utama kita. Kita menggunakan bahasa dengan memperhatikan kepentingan dan kebutuhan khalayak sasaran kita.

Pada saat kita menggunakan bahasa untuk berkomunikasi, antara lain kita juga mempertimbangkan apakah bahasa yang kita gunakan laku untuk dijual. Oleh karena itu, seringkali kita

${ }^{8}$ Ibid., 4 
mendengar istilah "bahasa yang komunikatif". Misalnya, kata makro hanya dipahami oleh orang-orang dan tingkat pendidikan tertentu, namun kata besar atau luas lebih mudah dimengerti oleh masyarakat umum. Kata griya, misalnya, lebih sulit dipahami dibandingkan kata rumah atau wisma. Dengan kata lain, kata besar, luas, rumah, wisma, dianggap lebih komunikatif karena bersifat lebih umum. Sebaliknya, kata-kata griya atau makro akan memberi nuansa lain pada bahasa kita, misalnya, nuansa keilmuan, nuansa intelektualitas, atau nuansa tradisional.

Bahasa sebagai alat ekspresi diri dan sebagai alat komunikasi sekaligus pula merupakan alat untuk menunjukkan identitas diri.

Melalui bahasa, kita dapat menunjukkan sudut pandang kita, pemahaman kita atas suatu hal,asal usul bangsa dan negara kita, pendidikan kita, bahkan sifat kita. Bahasa menjadi cermin diri kita, baik sebagai bangsa maupun sebagai diri sendiri.

c .Bahasa sebagai Alat Integrasi dan Adaptasi Sosial

Bahasa disamping sebagai salah satu unsur kebudayaan, memungkinkan pula manusia memanfaatkan pengalamanpengalaman mereka, mempelajari dan mengambil bagian dalam pengalaman-pengalaman itu, serta belajar berkenalan dengan orangorang lain. Anggota-anggota masyarakat hanya dapat dipersatukan secara efisien melalui bahasa. Bahasa sebagai alat komunikasi, lebih jauh memungkinkan tiap orang untuk merasa dirinya terikat dengan kelompok sosial yang dimasukinya, serta dapat melakukan semua kegiatan kemasyarakatan dengan menghindari sejauh mungkin bentrokan-bentrokan untuk memperoleh efisiensi yang setinggitingginya. Ia memungkinkan integrasi (pembauran) yang sempurna bagi tiap individu dengan masyarakatnya. ${ }^{9}$

Cara berbahasa tertentu selain berfungsi sebagai alat komunikasi, berfungsi pula sebagai alat integrasi dan adaptasi sosial.

${ }^{9}$ Ibid., 5 
Pada saat kita beradaptasi kepada lingkungan sosial tertentu, kita akan memilih bahasa yang akan kita gunakan bergantung pada situasi dan kondisi yang kita hadapi. Kita akan menggunakan bahasa yang berbeda pada orang yang berbeda. Kita akan menggunakan bahasa yang nonstandar di lingkungan teman-teman dan menggunakan bahasa standar pada orang tua atau orang yang kita hormati .

Pada saat kita mempelajari bahasa asing, kita juga berusaha mempelajari bagaimana cara menggunakan bahasa tersebut. Misalnya, pada situasi apakah kita akan menggunakan kata tertentu, kata manakah yang sopan dan tidak sopan. Bilamanakah kita dalam berbahasa Indonesia boleh menegur orang dengan kata Kamu atau Saudara atau Bapak atau Anda? Bagi orang asing, pilihan kata itu penting agar ia diterima di dalam lingkungan pergaulan orang Indonesia. Jangan sampai ia menggunakan kata kamu untuk menyapa seorang pejabat. Demikian pula jika kita mempelajari bahasa asing. Jangan sampai kita salah menggunakan tata cara berbahasa dalam budaya bahasa tersebut. Dengan menguasai bahasa suatu bangsa, kita dengan mudah berbaur dan menyesuaikan diri dengan bangsa tersebut.

4. Bahasa sebagai Alat Kontrol Sosial

Sebagai alat kontrol sosial, bahasa sangat efektif. Kontrol sosial ini dapat diterapkan pada diri kita sendiri atau kepada masyarakat. Berbagai penerangan, informasi, maupun pendidikan disampaikan melalui bahasa. Buku-buku pelajaran dan buku-buku instruksi adalah salah satu contoh penggunaan bahasa sebagai alat kontrol sosial. Ceramah agama atau dakwah merupakan contoh penggunaan bahasa sebagai alat kontrol sosial. Lebih jauh lagi, orasi ilmiah atau politik merupakan alat kontrol sosial. Kita juga sering mengikuti diskusi atau acara bincang-bincang (talk show) di televisi dan radio. klan layanan masyarakat atau layanan sosial merupakan salah satu wujud penerapan bahasa sebagai alat kontrol sosial. Semua itu merupakan kegiatan berbahasa yang memberikan kepada kita cara 
untuk memperoleh pandangan baru, sikap baru, perilaku dan tindakan yang baik. Di samping itu, kita belajar untuk menyimak dan mendengarkan pandangan orang lain mengenai suatu hal.

Contoh fungsi bahasa sebagai alat kontrol sosial yang sangat mudah kita terapkan adalah sebagai alat peredam rasa marah. Menulis merupakan salah satu cara yang sangat efektif untuk meredakan rasa marah kita. Tuangkanlah rasa dongkol dan marah kita ke dalam bentuk tulisan. Biasanya, pada akhirnya, rasa marah kita berangsur-angsur menghilang dan kita dapat melihat persoalan secara lebih jelas dan tenang

2 . Konsep Permainan Pada Anak

a. Hakikat Permainan

Pelaku permainan akan mengalami dan merasakan manfaat secara langsung. Hal ini berbeda dengan kegiatan belajar diruang kelas yang lebih menonjolkan aspek kognitif. Meskipun demikian, kegiatan belajar yang efektif adalah dilakukan dengan belajar langsung, dimana siswa bisa merasakan dan mengalami langsung apa yang mereka pelajari. Kegiatan bermain dan belajar berbeda jika ditinjau secara akademis. Keterampilan akademis, seperti berhitung, menulis dan membaca biasa dikuasai dengan proses belajar di kelas. Meskipun demikian bukan berarti aktivitas bermain tidak berperan penting, keterampilan lain yang berhubungan dengan Basic Life Skill, seperti keterampilan berkomunikasi, bersosialisasi, bernegosiasi, dan bekerjasama dalam tim, bisa dipelajari dari proses bermain.

Dimata anak-anak, ada beberapa alasan kenapa permainan dibutuhkan sebagai media pembelajarnya. Menurut Yayah, beberapa alasan tersebut adalah sebagai berikut:

1) Anak-anak membutuhkan pengalaman yang kaya, bermakna, dan menarik,

2) Otak anak senang pada sesuatu yang baru dan hal hal baru yang menantang dan menarik, 
3) Rangsangan otak sensori multimedia penting dalam pembelajaran. Makin banyak yang terlibat (visual, audio, dan audio visual) dalam suatu aktivitas, makin besar pula kemungkinan siswa untuk belajar,

4) Anak umumnya senang bergerak, jadi jangan lupa memasukan gerak dalam pembelajaran,

5) Pengulangan adalah kunci belajar. Berikan kegiatan yang membuat siswa dapat mengulang pembelajaran tanpa rasa bosan dan jenuh, (6) Permainan (games) menyenangkan bagi anak. Keinginan untuk belajar dapat meningkat dengan adanya tantangan dan terhabat oleh ancaman yang disertai oleh rasa tidak mampu atau kelelahan ${ }^{10}$

b. Kompetensi yang dicapai melalui hasil permainan

Permainan yang diselenggarakan dalam pembelajaran dapat meningkatkan kompetensi khsusnya kompetensi yang erat kaitannya dengan perkembangan anak. Ralibi mengemukakan tentang kompetensi dari hasil permainan adalah sebagai berikut:

1) Self Awareness, yaitu kemampuan menyadari emosi dan pikiran di dalam diri sendiri serta menyadari tindakan apa yang harus dilakukan atas emosi yang sedang disadarinya.

2) Self Direction, yaitu kemampuan menggunakan pilihanpilihan dalam mengahdapi persoalan.

3) Self Management, Yaitu keampuan mengelola ataumengorganisasi persoalan atautugas secara mandiri.

4) Empathy, kemampuan menyadari emosi yang dirasakan oleh orang lain.

${ }^{10}$ Yayah Kusbudian, Metode Pembelajaran Anak Usia Dini Melalui Permainan http://bdkbandung.kemenag.go.id/jurnal/249-metode-pembelajarananak-usia-dini-melalui-permainan, di akses tanggal 20 Septemberl 2017. 
5) Assertive, yaitu kemampuan mengkondisikan diri diantara perilaku submisif (cenderung mengikuti) dan agresif.

6) Followership, yaitu kemampuan memosisikan diri untuk dipimpin orang lain.

7) Craetive Thinking, yaitu kemampuan berpikir dengan car memadukan pengalaman pikiran dan tindakannya dalam menghadapi persoalan.

8) Team Work, yaitu kemampuan bekerjasama dalam sebuah tim.

9) Problem Solving, yaitu kemampuan memecahkan persoalan.

10) Oppeness, yaitu kemampuan membuka diri terhadap oranglain.

11) Team Spirit. yaitu kemampuan menghidupkan semangat secara kolektif.

12) Effective Comunication, yaitu kemampuan berinteraksi satu sama lain secara verbal maupun non verbal.

13) Self Communication, yaitu kemampuan beinteraksi satu sama lain baik secara verbal maupun nonverbal.

14) Self Motivation, yaitu kemampuan memacu motivasi di dalam diri. ${ }^{11}$

Kompetensi-kompetensi tersebut, merupakan asas untuk menumbuhkan keterampilan berbahasa pada anak melalui metodemetode permainan dalam meningkatkan aspek-aspek kebahasaan yang kuat.

c. Syarat pemilihan dan penggunaan alat dan bahan permainan

Selain permainan yang dapat dilaksanakan tanpa bantuan alat, permainan juga dapat dilakukan dengan alat bantu alat permainan. Beberapa aspek yang perlu

${ }^{11}$ Ralibi, M.I. Fun Teaching (Bekasi: Duha khazanah, 2008), h. 23. 
diperhatikan dalam memilih bahan dan peralatan belajar dan bermain anak yaitu:

1. Pilih alat atau bahan yang mengundang perhatian anak, Alat dan bahan dapat memuaskan kebutuhan

anak, menarik

minat dan menyentuh perasaan mereka baik dari war na, jenis, bentuk,

ukuran atau berat. Jenis dan bentuk alat belajar juga akan berpengaruh terhadap perkembangan belajar anak. Oleh karena itu pilih yang bobotnya tidak terlalu berat sehingga anak mudah memindah -mindahkannya, kecuali memang peralatan tersebut dirancang khusus untuk tidak dipindah, digeser atau dibawa oleh anak.

2. Pilih bahan yang mencerminkan karakteristik tingkat usia anak. Dalam mencari alat permainan kita harus mempelajari perkembangan dan ciri-ciri belajar anak sebagaimana karakteristik anak.

3. Pilih alat atau bahan yang memiliki unsur multiguna. Alat dan bahan mainan ini dapat memenuhi bermacammacam tujuan pengembangan atau jika memungkinkan seluruh aspek perkembangan anak dan dapat dipergunakan secara fleksibel dan serba guna. Misalnya ketika anak bermain dengan balok ia akan berfikir untuk membangun sesuatu dari balok (kognitif) membolakbalik/mengeksploras balok tersebut (motorik halus) membuat bangunan baru/aneh (kreatif) atau kerjasama dengan temannya untuk menyusun balok (sosial).

4. Alat permainan sebaiknya beraneka macam sehing ga anak dapat bereksplorasi dengan berbagai macam alat permainan. 
5. Pilih bahan yang dapat memperluas kesempatan anak untuk menggunakannya dengan bermacam cara. Tingkat kesulitan sebaiknya disesuaikan dengan rentang usia anak.

6. Peralatan mainan tidak terlalu rapuh

7. Pilih bahan yang tidak membedakan jenis kelamin dan tidak meniru-niru. Sebaiknya alat atau bahan yang dipilih tidak dibedakan berdasarkan jenis kelamin. Pada anak usia dini perlu diperkenalkan berbagai peran dan hal.

8. Pilih alat dan bahan yang sesuai dengan filsafat dan nafas pendidikan. Alat dan bahan ini sering disebut dengan APE (Alat

Permainan Edukatif) untuk mendapatkan dapat berkons ultasi dengan seorang ahli baik , ahli mainan, pendidik anak psikolog atau perawat an ak yang profesional.

d. Penggolongan kegiatan bermain anak berdasarkan dimensi perkembangan

Penggolongan kegiatan bermain sesuai dengan dimensi perkembangan anak menurut Moeslichatoen dibagi dalam 4 golongan yaitu: "Bermain secara soliter, bermain secara parallel, bermain secara asosiatif, dan bermain secara kooperatif". Bermain soliter artinya bermain sendiri tanpa teman. Bermain parallel artinya kegiatan bermain yang dilakukan sekelompok anak dengan menggunakan alat permainan yang sama, tetapi masing-masing anak bermain sendiri. Bermain Asosiatif artinya anak bermain dalam permainan yang sama tapi tidak ada peraturan. Sedangkan bermain kooperatif adalah Masing-masing anak memiliki peran tertentu guna mencapai tujuan bermain. Anak-anak dari kelompok usia akan 
menunjukan tahapan perkembangan bermain sosial yang berbedabeda. $^{12}$

Penggolongan kegiatan bermain tersebut diatas dilakukan oleh anak-anak sesuai dengan perkembangan anak secara fitrah. Penggolongan tersebut merupakan tahapan-tahapan perkembangan bermain anak. Anak dapat bermain sendiri dengan bimbingan orang tua atau guru, permainan saling meniru dengan teman, bermain bersama dengan permainan yang mengandung unsur kompetisi. Perkembangan kecerdasan personal anak sangat dirasakan manfaatnya. Dalam proses permainan terdapat unsur aturan-aturan yang harus ditaati, mengerti orang lain, toleransi, kerjasama dan persahabatan. Oleh karena itu melalui permainan anak dapat dirangsang dan dilatih kecerdasan personalnya karena anak dapat berinteraksi sosial dan berempati.

e. Kegiatan bermain anak berdasarkan kegemaran

Kegiatan bermain berdasarkan pada kegemaran anak, dibagi menjadi 4 macam, yaitu:

1. Bermain bebas dan spontan

2. Bermain Pura-pura, dapat dibedakan menjadi beberapa bentuk:

a) Minat pada personifikasi (bicara pada boneka atau benda-benda mati)

b) Bermain dengan menggunakan peralatan (minum dengan menggunakan cangkir kosong)

c) Bermain pura-pura dalam situasi tertentu, misalnya situasi dalam keluarga, tempat praktek dokter,dan sebagainya)

Pola bermain pura-pura merupakan permainan untuk mengembangkan imajinatif anak yang sangat unik, bahkan terkadang kurang difahami oleh orang dewasa. Oleh karena itu sebaiknya orang

${ }^{12}$ Moeslichatoen, Metode Pengajaran di Taman Kanak-Kanak (Jakarta: Roneka Cipta, 2004), h. 37 
dewasa disekitarnya dapat lebih faham dan mengembangkan secara maksimal kemampuan anak dalam berimajinasi tersebut.

3. Bermain dengan cara membangun dan menyusun. Bermain dalam bentuk seperti ini sangat baik untuk mengembangakan kreativitas anak Setiap anak akan menggunakan imajinasinya membentuk atau membangun sesuatu mengikuti daya khayalnya. Anak akan merasa bangga dan akan menunjukan kreasinya kepada teman atau gurunya. Membangun dan menyusun ini bukan hanya dengan menggunakan alat bantu (APE-Alat Permainan Edukatif), akan tetapi bentuk gambar, lukisan (finger painting), meronce, dll, merupakan bentuk lain dari kreatitivitas anak dalam hal membentuk dan membangun.

4. Bertanding atau berolah Raga

Bermain dengan jenis permainan yang mengandung unsur game atau pertandingan, baik juga dilakukan di sekolah. Permainan yang bermakna pertandingan hendaknya dilakukan dengan aturan sederhana dan jelas, dan usahakan tempo permainan tidak terlalu panjang. Berbagai kegiatan bermain yang megandung unsur pertandingan misalnya:

a) Belajar mendengar dan menguasai kosa kata

b) Belajar mendengar dan mengapresiasi nada musik

c) Permainan yang menuntut penguasaan anak dalam hal menjodohkan (kartu Kuartet, Domino,dan lain-lain)

d) Permainan yang menuntut penguasaan koordinasi motorik halus

\section{F. Bahan dan Alat permainan sesuai dengan Perkembangan Anak}

1. Bahan dan peralatan bermain bagi pengembangan motorik anak.

Sebaiknya sekolah memiliki tempat atau ruang khusus untuk aktivitas motorik anak. Sebaiknya anak diberikan ruang untuk melatih gerakan otot kasarnya (seluncuran, besi-besi panjatan, ayunan, arena sepeda, dll. Peralatan bermain yang beroda sebaiknya 
dapat digunakan oleh anak untuk mengembangkan aspek sosialnya. Anak bisa bermain bersama, bergantian, sehingga interaksi social dapat terjalin diantara mereka.

2. Bahan dan peralatan bermain bagi perkembangan kognitif anak.

Kemampuan kognitif yang dapat dikembangkan melalui kegiatan bermain: Kemampuan mengenal, mengingat, berpikir konvergen, divergen, dan member penilaian. Kegiatan bermain dilakukan dengan cara mengamati dan mendengar.Bahan atau peralatan yang dibutuhkan hendaknya membantu dalm perkembangan anak dalam mengamati dan mendengarkan. Contohnya: Papan pasak kecil,menara gelang, balok ukur, dan lainlain.

3. Bahan dan peralatan bermain bagi pengembangan kreativitas anak.

Bermain dapat meningkatkan kreativitas anak. Kreativitas bagi anak-anak adalah suatu permainan. Anak-anak mampu membuat apa saja yang mengasyikan untuk menjadi permainan yang mengasyikan dirinya. Anak anak tidak terbelenggu oleh berbagai tabu, gengsi, dan aturan seperti permainan orang dewasa. Kreativitas adalah karakter standar yang dimiliki setiap orang sebagai suatu karunia Allah swt., dan menjadikan manusia memiliki kelebihan dari mahlik Allah yang lainnya. Kreativitas harus terus distimulus agar dapat berkembang dengan baik. Permaina yang dilakukan bersama anak anak di sekolah sebaiknya perminan yang menantang kreatifitas anak secara maksimal.

Kemampuan berbahasa yang dapat dikembangkan melalui kegiatan bermain bertujuan untuk:

Menguasai bahasa reseptif (mendengar dan memahami apa yang didengar):

(1) Memahami perintah

(2) Menjawab pertanyaan 
(3) Mengikuti urutan peristiwa

b. Menguasai bahsa ekspresif yang meliputi:

(1) Menguasai kata-kata baru

(2) Menggunakan pola bicara orang dewasa

c. Berkomunikasi secara verbal dengan orang lain: berbicara sendiri atau berbicara pada orang lain

d. Keasyikan menggunakan bahasa

e. Bahan dan peralatan bermain bagi pengembangan emosi anak

Hal penting dalam melakukan kegiatan untuk mengembangkan emosi diantaranya harus dapat :

1. Meningkatkan kemampuan untuk memahami perasaan (dengan cara menyebutkan perasaan, menerima perasaan, mengekspresikan secara tepat, dan memahami perasaan orang lain

2. Meningkatkan kemampuan berlatih membuat pertimbangan

3. Meningkatkan kemampuan memahami perubahan

4. Menyenangi diri sendiri

Moeslichatoen menyatakan peralatan bermain dan permainan yang dilakukan sebaiknya dapat digunakan secara bersama atau permainan dapat dilakukan bersama agara memperoleh makna, diantaranya adalah:

a. Setiap perbuatan yang dilakukan dalam interaksi dengan anak lain itu ada dampaknya

b. Setiap tingkah laku sosial yang positif yang dapat diterima anak lain

c. Setiap anak akan dapat melkukan keinginannya asal dilaksanakan secara secara wajar

d. Setiap anak dapat menuntut haknya dengan cara yang dapat diterima anak lain

e. Setiap anak dapat mengekspresikan perasaannya bila dilaksanakan dengan cara yang dapat diterima anak lain. ${ }^{13}$

${ }^{13}$ Ibid, h. 56. 
Mengamati pernyataan diatas, dapat disimpulkan bahwa perkembangan sosial yang harus dicapai anak merupakan wujud dari pengoptimalan kecerdasan personal, khususnya Kecerdasan Interpersonal. Hal yang tidak dapat dipungkiri bahwa bermain merupakan bagian utama dari kehidupan anak.

Kostelnik dalam montolalu mengemukakan tentang karakteristik bermain pada anak sebagai berikut:"Play is fun, not serious, meaningful, active, voluntary, intrinsically motivated, rule governed". ${ }^{14}$ Bargen mengemukakan terdapat empat kategori bermain, yaitu:

a. Bermain bebas (free play). Dalam bermain bebas, anak memilih apapun yang dimainkannnya, bagaimana bermain, dan di mana mereka bermain. Bermain seperti ini menuntut para pendidik untuk menyediakan lingkungan yang aman, menyediakan berbagai peralatan dan bahan yang mendukung

b. Bermain terbimbing (guided play). Bermain terbimbing memiliki aturan, lebih sedikit pilihan, dan adanya pengawasan dari orang dewasa.

c. Bermain yang diarahkan (directed play). Dalam bermain ini kegiatan bermain ditentukan oleh orang dewasa.

d. Work disguised play. Bermain ini menggambarkan kegiatan diorientasikan pada tugas tertentu, dan orang dewasa berusaha mentransformasikannya kedalam kegiatan bermain terbimbing atau yang diarahkan.

Dalam pengimplentasiannya para pendidik dapat mengintegrasikan pendekatan belajar melalui bermain tersebut dalam metode-metode pembelajaran lain yang digunakan misalnya bercakap-cakap, bercerita, karyawisata, sosiodrama atau bermain

${ }^{14}$ Montolalu. W, Bermain Dalam Kelompok, Bermain Bola, Bermain dengan Angka. (Jakarta: Grasindo, 2008), h. 105. 
peran, proyek, eksperimen, tanya jawab, demonstrasi, dan pemberian tugas.

\section{B. Langkah-langkah dalam Kegiatan Bermain}

Bermain merupakan upaya bagi anak untuk mengungkapkan hasil pemikiran dan perasaan serta cara anak menjelajah lingkungannya. Bermain juga membantu anak untuk menjalin hubungan soial antar anak. Ketika anak mulai masuk ke suatu lembaga pendidikan, anak-anak harus mulai bisa menempatkan diri pada posisi yang tepat, karena dalam beberapa hal kegiatan bermain di sekolah berbeda dengan kegiatan bermain di rumah.

1. Menentukan Tujuan dan Tema Kegiatan Bermain

Tujuan kegiatan bermain bagi peserta didik adalah untuk mengembangkan selutuh aspek perkembangan anak, baik motorik, kognitif, bahasa, kreativitas, emosi dan sosial. Dalam kegiatan bermain itu terlebih dahulu dikomunikasikan kepada anak dan diutarakan apa yang akan diperoleh dari kegiatan bermain tersebut dalam bahasa yang dapat difahami oleh anak-anak. Setelah menentukan tujuan, sesuaikan dengan tema yang telah ditetapkan dan tertera dalam kurikulum. Dibawah ini terdapat contoh bagaimana menentukan tujuan dan tema.

Tujuan bermain: Setelah anak melakukan kegiatan bermain, anak dapat menguasai cara:

a. Menghindari pertentangan

b. Berbagi kesempatan atau giliran

c. Menuntut hak dengan cara yang dapat diterima

d. Mengkomunikasikan keinginan yang dapat diterima

e. Menghargai hasil karya/usaha orang lain, dll

Tema Bermain: Sesuaikan dengan tujuan yang telah ditetapkan dalam SKH, misalnya Tema Alat Komunikasi. Dilakukan permainan "pesan berantai" dengan cara berbisik, diadakan secara berkelompok dan mengandung unsur perlombaan. 


\section{Menentukan Macam Kegiatan Bermain}

Dalam menentukan jenis kegiatan bermain harus diperhatikan kemungkinan-kemungkinan yang akan menjadi hambatan dalam melakukan kegiatan. Kegiatan permainan sebaiknya merupakan permaianan yang mendidik atau lebih dikenal dengan "Edu Fun Game". Permainan yang seru, menyenangkan, tetapi sarat dengan maknhga pendidikan dalam rangka membantu anak untuk mengembangkan berbagai jenis kecerdasannya. Jika permainan yang dilakukan tidak dapat mengoptimalkan seluruh bidang kecerdasan, guru dapat memfokuskan pada salah satu jenis kecerdasan apa yang ingin dicapai sebagai tujuan pembelajaran. Hal ini dapat menjadi dasar dalam pemilihan permainan. Permainan yang baik adalah permainan yang dapat mengakomodir seluruh bidang kecerdasan anak secara optimal. Waktu permainan juga perlu diperhatikan, agar dalam waktu yang cukup, dapat digunakan semaksimal mungkin dan dapat memberi kesempatan kepada seluruh anak untuk mengikuti kegiatan. Selama kegiatan permainan berlangsung, perlu diperhatikan keselamatan anak-anak. Aktivitas anak yang kadang tidak terkontrol oleh guru. Kecelakaan kecil mungkin saja terjadi apabila kegiatan permainan tersebut dilakukan penuh dengan kegiatan fisik.

3. Menentukan Tempat dan Ruang Bermain.

Tempat bermain ditentukan di luar atau di dalam ruangan, tergantung fasilitas yang ada di sekolah, jenis permainan yang akan dilakukan, cuaca, dan tema serta tujuan kegiatan permainan tersebut. Dalam hal ini guru perlu menyiapkan kegiatan alternative apabila terjadi sesuatu yang diluar dugaan. Tanpa mengurangi tujuan pembelajaran yang ditetapkan, lakukan kegiatan permainan alternatif, sehingga kegiatan pembelajaran tidak terhambat.

4. Menentukan Bahan dan Peralatan Bermain.

Sebelum melakukan kegiatan bermain, berbagai bahan dan peralatan pendukung hendaknya dipersiapkan dengan seksama, karena akan menentukan kelancaran kegiatan pembelajaran melalui 
permainan ini. Syarat utama bahan dan alat yang diguanakan adalah aman untuk dipegang, atau dimainkan oleh anak. Keselamatan anak adalah hal yang paling utama untuk diperhatikan.

5. Menentukan Urutan Langkah Bermain

Urutan langkah permainan benar-benar dipahami oleh guru. Dalam membimbing anak bermain, komunikasikan terlebih dahulu peraturan yang harus ditaati oleh anak. Hargai pendapat anak apabila anak mengemukakan pendapat yang berhubungan dengan pelaksanaan permainan tersebut. Urutan langkah permainan ini terdapat dalam permainan yang sifatnya terpimpin, atau dibimbing langsung oleh guru. Sedangkan untuk permainan yang sifatnya bebas (anak menentukan sendiri permainannya) peraturan permainan berkisar pada waktu, mengingatkan untuk bias saling berbagi antar sesama teman. Perencanaan permainan juga harus memperhatikan kegiatan pra bermain, saat bermain dan kegiatan penutup.

\section{Ihwal Keterampilan Berbahasa Indonesia}

Sebagai seorang guru, kita memerlukan media bahasa dalam upaya membelajarkan anak, dalam menjalani profesi dan kehidupan sehari-hari. Dalam berkomunikasi kita menggunakan keterampilan berbahasa. Ada orang yang memiliki keterampilan berbahasa secara optimal sehingga tujuan komunikasinya mudah tercapai dalam setiap peristiwa komunikasi, ada pula yang sangat lemah tingkat keterampilannya sehingga suasana komunikasi menjadi buruk. Oleh karena itu, anak-anak akan dilatih menguasai keterampilan berbahasa sehingga dapat memiliki kemampuan berbahasa. Keterampilan berbahasa ada empat aspek, yaitu: keterampilan berbicara, menyimak, menulis, dan membaca.

Santoso, dkk., mengatakan bahwa keterampilan berbahasa tulis terdiri dari keterampilan membaca dan menulis. Membaca merupakan kegiatan memahami bahasa tulis, sedangkan menulis adalah kegiatan menggunakan bahasa tulis sebagai sarana untuk 
mengungkapkan gagasan. ${ }^{15}$ Sedangkan keterampilan berbahasa lisan terdiri dari keterampilan menyimak dan berbicara. Keterampilan menyimak dan berbica

\section{Keterampilan Berbicara}

Keterampilan berbicara adalah salah satu keterampilan berbahasa sebagai kemampuan mengucapkan bunyi-bunyi artikulasi atau kata-kata untuk mengekspresikan, menyatakan serta mengungkapkan pendapat atau pikiran dan perasaan kepada seseorang atau kelompok secara lisan, baik secara berhadapan ataupun dengan jarak jauh. Berbicara sebagai salah satu aspek keterampilan berbahasa memiliki keterkaitan erat dengan aspek keterampilan berbahasa lainnya, yaitu antara berbicara dengan menyimak, berbicara dengan menulis, dan berbicara dengan membaca.

a) Hubungan Berbicara dengan Menyimak

Berbicara dan menyimak adalah dua kegiatan yang berbeda namun berkaitan erat dan tak terpisahkan. Kegiatan menyimak didahului oleh kegiatan berbicara. Kegiatan berbicara dan menyimak saling melengkapi dan berpadu menjadi komunikasi lisan, seperti dalam bercakap-cakap, diskusi, bertelepon, tanya-jawab, interview, dan sebagainya.

Kegiatan berbicara dan menyimak saling melengkapi, tidak ada gunanya orang berbicara bila tidak ada orang yang menyimak. Tidak mungkin orang menyimak bila tidak ada orang yang berbicara. Melalui kegiatan menyimak siswa mengenal ucapan kata, struktur kata, dan struktur kalimat.

b) Hubungan Berbicara dengan Membaca

Berbicara dan membaca berbeda dalam sifat, sarana, dan fungsi. Berbicara bersifat produktif, ekspresif melalui sarana bahasa lisan

\footnotetext{
${ }^{15}$ Puji Santoso, dkk., Materi dan pembelajaran Bahasa di SD (Jakarta: Universitas terbuka, 2005), 6.3.
} 
dan berfungsi sebagai penyebar informasi. Membaca bersifat reseptif melalui sarana bahasa tulis dan berfungsi sebagai penerima informasi.

Bahan pembicaraan sebagian besar didapat melalui kegiatan membaca. Semakin sering orang membaca semakin banyak informasi yang diperolehnya. Hal ini merupakan pendorong bagi yang bersangkutan untuk mengekspresikan kembali informasi yang diperolehnya antara lain melalui berbicara.

c) Hubungan Berbicara dengan Menulis

Kegiatan berbicara maupun kegiatan menulis bersifat produktifekspresif. Kedua kegiatan itu berfungsi sebagai penyampai informasi. Penyampaian informasi melalui kegiatan berbicara disalurkan melalui bahasa lisan, sedangkan penyampaian informasi dalam kegiatan menulis disalurkan melalui bahasa tulis.

Informasi yang digunakan dalam berbicara dan menulis diperoleh melalui kegiatan menyimak ataupun membaca. Keterampilan menggunakan kaidah kebahasaan dalam kegiatan berbicara menunjang keterampilan menulis. Keterampilan menggunakan kaidah kebahasaan menunjang keterampilan berbicara

Dalam berbicara si pengirim pesan mengirimkan pesan dengan menggunakan bahasa lisan. Kemudian, dalam menyimak si penerima pesan berupaya memberi makna terhadap bahasa lisan yang disampaikan orang lain dengan menggunakan bahasa tulis. Di pihak lain, dalam membaca si penerima pesan berupaya memberi makna terhadap bahasa tulis yang disampaikan orang lain.

Dalam mengirimkan pesan antara lain si pengirim harus memiliki keterampilan dalam melakukan proses ecoding. Sebaliknya dalam menerima pesan si penerima harus memiliki keterampilan dalam melakukan proses decoding. Orang yang akan mengajarkan suatu bahasa hendaknya mengetahui dengan baik bahasa yang akan 
diajarkannya serta sanggup berbicara dalam bahasa tersebut. ${ }^{16}$. Selanjutnya, dalam menulis, si penulis pesan mengirimkan pesan da sangat erat kaitannya, bersifat resiprokal. Dalam kehidupan seharihari penyimak dan pembicara dan dari pembicara menjadi penyimak. $^{17}$

Keterampilan berbahasa bermanfaat dalam melakukan interaksi proses pembelajaran di kelas, agar para peserta didik aktif dan trampil berkomunikasi mengungkapkan pikiran dan mengekpresikan perasaannya srta gagasannya untuk menyampaikan pada orang lain.

\section{Keterampilan menyimak}

Keterampilan menyimak merupakan bagian dari keterampilan berbahasa yang sangat esensial, sebab keterampilan menyimak merupakan dasar untuk menguasai suatu bahasa. Anak kecil yang mulai belajar berbahasa, dimulai dengan menyimak rentetan bunyi yang didengarnya, belajar menirukan, kemudian mencoba untuk menerapkan dalam pembicaraan. Setelah masuk sekolah, anak tersebut belajar membaca dari mengenal huruf atau bunyi bahasa yang diperlihatkan oleh guru sampai pada mengucapkan bunyi-bunyi bahasa atau kegiatan menirukan bunyi-bunyi bahasa tersebut. Pada situasi ini, anak sudah mulai menulis. Demikian seterusnya sampai anak bisa mengutarakan isi pikiran melalui bahasa lisan maupun bahasa tulisan, dan mampu memahami isi pikiran orang lain yang diungkapkan melalui bahasa lisan maupun bahasa tulisan.

\section{Keterampilan Membaca}

Membaca adalah kemampuan mengenali dan memahami isi sesuatu yang tertulis (lambang-lambang tertulis) dengan melafalkan atau mencernanya dalam hati. Pada hakikatnya, membaca adalah proses komunikasi antara pembaca dengan penulis melalui teks yang

\footnotetext{
${ }^{16}$ Masnur Muslih, Bahasa Indonesia Pada era Globalisasi (Jakarta: Bumi Aksara, 2010), 164.

${ }^{17}$ Ibid., 6.31
} 
ditulisnya. Maka, secara langsung, di dalamnya terjadi hubungan kognitif antara bahasa lisan dengan tulisan. Tarigan berpendapat bahwa membaca adalah proses yang dilakukan dan dipergunakan oleh pembaca untuk memperoleh pesan yang hendak disampaikan oleh penulis melalui media kata-kata atau bahasa tulis.

Membaca merupakan salah satu keterampilan berbahasa yang mempunyai pengertian: 1) membaca sebagai proses melisankan paparan tulis, 2) membaca sebagai kegiatan mempersepsi tuturan tulis, 3) membaca adalah penerapan seperangkat keterampilan kognitif untuk memperoleh pemahaman dari tuturan yang dibaca, 4) membaca sebagai proses pemberian makna kepada simbol-simbol visual, 5) keterampilan berbahasa yang mempunyai kegiatan melisankan, mempersepsi penerapan keterampilan kognitif dan pemahaman berfikir, dan bernalar serta pemberian makna terhadap simbol-simbol visual, 6) membaca proses yang dilakukan serta dipergunakan oleh pembaca untuk memperoleh pesan yang hendak disampaikan oleh penulis melalui media kata-kata/bahasa tulis. ${ }^{18}$

Membaca merupakan kemampuan yang kompleks, membaca bukanlah kegiatan memandangi lambang-lambang tertulis sematamata. Bermacam-macam kemampuan dikerahkan oleh seorang pembaca agar dia mampu memahami materi yang dibacanya. Pembaca berupaya supaya lambang-lambang yang dilihatnya itu menjadi lambang-lambang yang bermakna baginya.

\section{Keterampilan Menulis}

Menulis merupakan komunikasi tidak langsung yang berupa pemindahan pikiran atau perasaan dengan memanfaatkan grafologi, struktur bahasa, dan kosakata dengan menggunakan simbol-simbol sehingga dapat dibaca seperti apa yang diwakili oleh simbol tersebut. Semi mengatakan bahwa " menulis pada hakikatnya

\footnotetext{
${ }^{18}$ Haryadi Rahim, Retorika Membaca: Model Membaca dan Teknik (Semarang: Rumah Indonesia, 2008), 1-2.
} 
merupakan pemindahan pikiran atau perasaan ke dalam bentuk lambang bahasa." 19

Mengkombinasikan dan menganalisis setiap unsur kebahasaan dalam sebuah karangan merupakan suatu keharusan bagi penulis. Dari sinilah akan terlihat sejauh mana pengetahuan yang dimiliki penulis dalam menciptakan sebuah karangan yang efektif. Kosakata dan kalimat yang digunakan dalam kegiatan menulis harus jelas agar mudah dipahami oleh pembaca. Di samping itu, jalan pikiran dan perasaan penulis sangat menentukan arah penulisan sebuah karya tulis atau karangan yang berkualitas. Dengan kata lain hasil sebuah karangan yang berkualitas umumnya ditunjang oleh keterampilan kebahasaan yang dimiliki seorang penulis.

Penulis harus sudah memahami karakteristik keterampilan menulis karena sangat menentukan dalam ketepatan penyusunan perencanaan, pelaksanaan, maupun penilaian keterampilan menulis. Sudah dapat dipastikan tanpa memahami karakteristik keterampilan menulis guru yang bersangkutan tak mungkin menyusun perencanaan, pelaksanaan, dan penilaian pembelajaran menulis yang akurat, bervariasi, dan menarik. Ada empat karakteristik keterampilan menulis yang sangat menonjol, yakni;

1. keterampilan menulis merupakan kemampuan yang kompleks;

2. keterampilan menulis condong ke arah skill atau praktik;

3. keterampilan menulis bersifat mekanistik;

4. penguasaan keterampilan menulis harus melalui kegiatan yang bertahap atau akumulatif.

Keterampilan menulis menuntut kemampuan yang kompleks. Penulisan sebuah karangan yang sederhana sekalipun menuntut kepada penulisnya kemampuan memahami apa yang hendak ditulis dan bagaimana cara menulisnya. Persoalan pertama menyangkut isi

\footnotetext{
${ }^{19}$ Semi, Atar. 1998. Menulis Efektif. (Padang: Angkasa, 1998),
} 
karangan dan persoalan kedua menyangkut pemakaian bahasa serta bentuk atau struktur karangan. Pembelajaran keterampilan menulis yang tidak memperhatikan kedua hal tersebut di atas pasti akan mengalami ketidakberesan atau kegagalan.

Keterampilan menulis lebih condong ke arah praktik ketimbang teori. Ini tidak berarti pembahasan teori menulis ditabukan dalam pengajaran menulis. Pertimbangan antar praktek dan teori sebaiknya lebih banyak praktek dari teori.

Keterampilan menulis bersifat mekanistik. Ini berarti bahwa penguasaan keterampilan menulis tersebut harus melalui latihan atau praktik. Dengan perkataan lain semakin banyak seseorang melakukan kegiatan menulis semakin terampil menulis yang bersangkutan. Karakteristik keterampilan menulis seperti ini menuntut pembelajaran menulis yang memungkinkan siswa banyak latihan, praktek, atau mengalami berbagai pengalaman kegiatan menulis.

Di samping harus bervariasi, menulis juga perlu sistematis, bertahap, dan akumulatif. Berlatih menulis yang tidak terarah apalagi kurang diawasi guru membuat kegiatan siswa tidak terarah bahkan sering membingungkan siswa. Mereka tidak tahu apakah mereka sudah bekerja benar, atau mereka tidak tahu membuat kesalahan yang berulang. Latihan mengarang terkendali disertai diskusi di mana sangat diperlukan dalam memahami dan menguasai keterampilan menulis.

Secara umum, tulisan terbagi ke dalam jenis-jenis berikut: narasi, eksposisi, deskripsi, argumentasi, dan persuasi. Di berikut ini akan dijelaskan satu per satu.

a. Eksposisi

Eksposisi biasa juga disebut pemaparan, yakni salah satu bentuk karangan yang berusaha menerangkan, menguraikan atau menganalisis suatu pokok pikiran yang dapat memperluas pengetahuan dan pandangan seseorang. Penulis berusaha memaparkan kejadian atau masalah secara analisis dan terperinci 
memberikan interpretasi terhadap fakta yang dikemukakan. Dalam tulisan eksposisi, teramat dipentingkan informasi yang akurat dan lengkap. Eksposisi merupakan tulisan yang sering digunakan untuk menyampaikan uraian ilmiah, seperti makalah, skripsi, tesis, desertasi, atau artikel pada surat kabar atau majalah.

Untuk menghasilkan tulisan ekposisi yang baik maka pikiran utama dan pikiran penjelas harus diorganisir dalam bentuk kerangka karangan yang pada umumnya dibagi dalam tiga bagian yaitu, bagian pembuka (pendahuluan) bagian pengembangan (isi), dan bagian penutup yang merupakan penegasan ide. Untuk karangan yang bersifat kompleks, harus diuraikan dalam bentuk sub-bagian yang lebih rinci

b. Deskripsi

Deskrisi adalah pemaparan atau penggambaran dengan katakata suatu benda, tempat, suasana atau keadaan. Seorang penulis deskripsi mengharapkan pembacanya, melalui tulisannya, dapat “ melihat' apa yang dilihatnya, dapat 'mendengar' apa yang didengarnya, 'merasakan' apa yang dirasakanya, serta sampai kepada 'kesimpulan' yang sama dengannnya. Dari sini dapat disimpulkan bahwa deskripsi merupakan hasil dari obesrvasi melalui panca indera, yang disampaikan dengan kata-kata.

c. Narasi (kisahan)

Narasi atau kisahan merupakan corak tulisan yang bertujuan menceritakan rangkaian peristiwa atau pengalaman manusia (tokoh) berdasarkan perkembangan dari waktu ke waktu. Paragraf narasi itu dimaksudkan untuk memberi tahu pembaca atau pendengar tentang sesuatu yang telah diketahui atau sesuatu yang dialami oleh penulisnya. Narasi lebih menekankan pada dimensi latar dan adanya alur atau konflik.

d. Argumentasi

Argumentasi merupakan corak tulisan yang bertujuan membuktikan pendapat penulis meyakinkan atau mempengaruhi 
pembaca agar amenerima pendapanya. Argumentasi berusaha meyakinkan pembaca. Cara menyakinkan pembaca itu dapat dilakukan dengan jalan menyajikan data, bukti, atau hasil-hasil penalaran.

e. Persuasi

Persuasi adalah karangan yang berisi paparan berdaya-ajuk, ataupun berdaya himbau yang dapat membangkitkan ketergiuran pembaca untuk meyakini dan menuruti himbauan implisit maupun eksplisit yang dilontarkan oleh penulis. Dengan kata lain, persuasi berurusan dengan masalah mempengaruhi orang lain lewat bahasa.

Bahasa Indonesia adalah bahasa yang terpenting di kawasan Republik Indonesia. Kedudukan bahasa Indonesia sangat penting. Hal ini terutama berkaitan dengan Sumpah pemuda 1928. Dengan begitu, bahasa Indonesia sangat penting di pelajari anak-anak, antara lain:

1. Sebagai alat untuk mengembangkan kemampuan berkomunikasi dengan lingkungan,

2. Sebagai alat untuk mengembangkan kemampuan intelektual anak,

3. Sebagai alat untuk mengembangkan ekspresi anak,

4. Sebagai dasar untuk mempelajari berbagai ilmu dan tingkatan pendidikan selanjutnya. $^{20}$

Untuk menumbuhkan keterampilan berbahasa pada anak, maka pembelajaran bahasa diarahkan agar anak mampu menggunakan dan mengekpresikan pemikirannya dengan menggunakan kata-kata. Dengan kata lain pembelajaran bahasa Indonesia lebih diarahkan agar a nak dapat:

1. mengolah kata secara komprehensif.

\footnotetext{
${ }^{20}$ Isah Cahyani, Pembelajaran Bahasa Indonesia (Jakarta: Dirjen Pendidikan Islam DEPAG RI), 42
} 
2. mengekspresikan katakata tersebut dalam bahasa tubuh (ucapan dan perbuatan) yang dapat dipahami oleh orang lain.

3. mengerti setiap kata, mengartikan dan menyampaikannya secara utuh kepada orang lain.

4. berargumentasi, meyakinkan orang melalui kata-kata yang diucapkannya.

Keterampilan bahasa merupakan salah satu dari bidang pengembangan kemampuan dasar yang dipersiapkan untuk meningkatkan kemampuan dan kreativitas anak sesuai dengan tahap perkembangannya. Pengembangan bahasa bertujuan agar anak mampu mengungkapkan pikiran melalui bahasa yang sederhana secara tepat, mampu berkomunikasi secara efektif dan membangkitkan minat untuk dapat berbahasa Indonesia yang baik dan benar.

Konsep menumbuhkan keterampilan berbahasa anak untuk memperbaiki aspek kebahasaan di antaranya sebagai berikut:

1. Meningkatkan kompetensi guru SD

Kompetensi guru SD yang harus ditingkatkan terutama kompetensi dalam hal-hal berikut:

a. Memahami konsep, teori, dan materi berbagai aliran linguistik yang terkait dengan pengembangan materi pembelajaran bahasa,

b. Memahami hakekat bahasa dan memperoleh bahasa,

c. Memahami kedudukan, fungsi, dan ragam bahasa, dan

d. Menguasai kaidah bahasa Indonesia sebagai rujukan penggunaan bahasa Indonesia yang baik dan benar.

Dengan kompetensi tersebut diharapkan guru SD dapat melaksanakan pembelajaran aspek kebahasaan sesuai dengan prinsipprinsip pembelajaran bahasa terutama dalam hal membetulkan kesalahan bahasa pada siswa karena aspek kebahasaan diajarkan hanya untuk membetulkan kesalahan ujaran siswa. Jika bahasa siswa dalam situasi resmi menyalahi kaidah bahasa, guru barulah 
"menyadarkan " siswa tentang kesalahan yang diperbuat dengan mengajarkan materi kebahasaan sesuai dengan kesalahan bahasa siswa. Sebaliknya, jika bahasa siswa dalam situasi tidak resmi menyalahi kaidah bahasa, guru tidak perlu membahas materi kebahasaan tersebut. Jadi, materi kebahasaan diajarkan kepada siswa sesuai dengan jenis kesalahan bahasa yang diperkuat siswa terutama dalam penggambaran situasi berbahasa resmi. Dengan kata lain, aspek kebahasaan baru diperlukan untuk dibahas ketika guru menemukan kesalahan berbahasa pada siswa, baik dalam bahasa lisan maupun bahasa tulisan.

2. Menyusun buku ajar kebahasaan berdasarkan kesalahan bahasa siswa

Buku ajar berdasarkan kesalahan bahasa siswa ini tentu saja disusun berdasarkan penelitian terhadap kesalahan bahasa siswa terutama terkait dengan ketrampilan berbahasa nyata terutama ketrampilan produktif (berbicara dan menulis) dalam situasi resmi yang menuntut penggunaan bahasa normatif, bahasa yang sesuai dengan kaidah bahasa.

3. Mengadakan penelitian tentang perkembangan grametika bahasa Indonesia anak usia sekolah

Hasil penelitian tentang perkembangan gramatika bahasa Indonesia anak usia sekolah ini sangat penting sebagai pedoman bagi perancang buku atau guru dalam menyiapkan materi dan tugas kebahasaan sehingga materi dan tugas-tugas yang diberikan sesuai dengan tingkat perkembangan kejiwaan siswa.

\section{PENUTUP}

Metode bermain merupakan cara yang digunakan untuk rencana menyeluruh mengenai penyajian bahasa secara sistematis berdasarkan pendekatan yang dilakukan berdasarkan pada tingkat kemampuan pemahaman anak. Keterampilan berbahasa Indonesia, meliputi: berbicara, menyimak, membaca, dan menulis. Konsep 
menumbuhkan keterampilan berbahasa bagi anak melalui metode bermain yakni: hakikat bermain, kompetensi yang dicapai melalui permainan, penggolongan kegiatan bermain anak berdasarkan dimensi perkembangan, syarat pemilihan dan penggunaan alat dan bahan permainan, kegiatan bermain anak berdasarkan kegemaran, bahan dan alat permainan sesuai dengan perkembangan anak.

\section{DAFTAR PUSTAKA}

Badudu, J.S. Pelik-Pelik Bahasa Indonesia, Bandung: CV. Pustaka Prima 1984.

Danar Santi, Pendidikan Anak Usia Dini, Cet.I., Jakarta: PT. Indeks, 2009.

Cahyani, Isah, Pembelajaran Bahasa Indonesia, Jakarta: Dirjen Pendidikan Islam DEPAG RI, 2009.

Jujun S.Suriasumantri, Filsafat Ilmu Sebua Penantar Populer, Jakarta:Pustaka Sinar arapan, 1998.

Rahim, Haryadi. Retorika Membaca: Model Membaca dan Teknik, Semarang: Rumah Indonesia, 2008.

Suhendi, A., dkk Mainan dan Permainan, Jakarta: PT. Gramedia. 2001.

Syamsuddin Asyrofi, dkk, Metodologi pembelanjaran Bahasa Arab, Yogyakarta : Pokja Akademik UIN Sunan Kalijaga, 2006.

Mustakim, Membina Kemampuan Berbahasa Panduan Kearah Kemahiran Berbahasa, Jakarta: Gramedia, 1994.

Moeslichatoen, Metode Pengajaran di Taman Kanak-Kanak, Jakarta: Roneka Cipta, 2004. 
Solehuddin, Konsep Dasar Pendidikan Prasekolah, Bandung: FIPUPI Indonesia, 2000.

Muslih, Masnur. Bahasa Indonesia Pada era Globalisasi, Jakarta: Bumi Aksara, 2010.

Montolalu. W, Montolalu. W Bermain Dalam Kelompok, Bermain Bola, Bermain dengan Angka, Jakarta: Grasindo, 2008.

Ralibi, M.I. Fun Teaching, Bekasi: Duha khazanah, 2008.

Santoso, Puj, dkk., Materi dan pembelajaran Bahasa di SD, Jakarta: Universitas terbuka, 2005.

Yayah Kusbudian, Metode Pembelajaran Anak Usia Dini Melalui Permainan http://bdkbandung.kemenag.go.id/jurnal/249metode-pembelajaran-anak-usia-dini-melalui-permainan, di akses tanggal 20 November 2017 